\title{
Do ICT Competences Support Educational Attainment at University?
}

\author{
Kurt De Wit \\ Office for Educational Policy, \\ University of Leuven, \\ Leuven, Belgium
}

kurt.dewit@dowb.kuleuven.be

\author{
Dirk Heerwegh \\ Business \& Decision Life Sciences, \\ Sint-Lambrechts-Woluwe, \\ Belgium
}

dirk.heerwegh@businessdecision.com

\author{
Jef C. Verhoeven \\ Centre for Sociological Research, University of Leuven, \\ Leuven, Belgium \\ jef.verhoeven@soc.kuleuven.be
}

\section{Executive Summary}

Taking into account that universities assume students will have at least some basic knowledge of the use of computers and the Internet, we hypothesize that the command of ICT skills by freshmen could have an influence on their educational attainment. To test this hypothesis an online questionnaire was used, which was answered by a representative sample of 1,529 freshmen studying at a large university. Two explanatory models were developed. First, using regression analysis the predictive power of the academic pathways model for the educational attainment of freshmen was tested. Second, the personal knowledge management model was developed in order to discover whether ICT competences contribute to the prediction of educational attainment and, if so, to what extent. Educational attainment was measured in terms of persistence of study choice at the end of the academic year, attained study efficiency at the end of the academic year, and GPA (Grade Point Average) at the end of the academic year. Three types of ICT skills were included in the second model: ICT social contact skills, basic ICT skills, and maintenance skills. Four factors are very powerful in predicting a student's educational attainment: the GPA in secondary school, the number of hours spent weekly on the study of maths in secondary school, the study of classical languages in secondary school, and any ambivalent feelings about the chosen study subject. Contrary to our expectations, ICT social contact skills and basic ICT skills do not provide a better prediction of educational attainment, whereas maintenance skills do; however, the latter predict a lower attainment.

Material published as part of this publication, either on-line or in print, is copyrighted by the Informing Science Institute. Permission to make digital or paper copy of part or all of these works for personal or classroom use is granted without fee provided that the copies are not made or distributed for profit or commercial advantage AND that copies 1) bear this notice in full and 2) give the full citation on the first page. It is permissible to abstract these works so long as credit is given. To copy in all other cases or to republish or to post on a server or to redistribute to lists requires specific permission and payment of a fee. Contact Publisher@InformingScience.org to request redistribution permission.
Keywords: pedagogical issues, postsecondary education, media in education, country-specific developments, computer-mediated communication, personal knowledge management

\section{Introduction}

Educational attainment is the result of dozens of factors. As will be shown later, many of these factors have been 
included in research in order to explain the position of youngsters in a particular educational system. For instance, in explaining the educational attainment of a large sample of UK citizens, Scherger and Savage (2010) refer to age, gender, father's occupational class, educational qualifications of the respondent (type of diploma), ethnicity, and index of parental socialization. These are definitely very important factors for understanding why a person attains a particular level of education, but are certainly not all that can be found in relevant research. Many researchers use these variables, but add more. Contrary to expectations due to the great importance of ICT in our world, we did not find a model in which educational attainment was also seen as (partly) a result of the level of ICT competences of students or their use of it.

There are probably no universities were a student can survive without a reasonable knowledge of ICT. However, there is little research available showing that ICT knowledge might matter with regard to educational attainment at university. Some authors offer indicators confirming the hypothesis that those who have ICT equipment at home attain higher educational levels. For example, Schmitt and Wadsworth (2006) show that, in the UK, PC ownership goes together with the number of GCSEs obtained and with an increase in the probability of passing at least one A-level. Of course, PC ownership does not indicate much about the ICT competences of the owner. In fact, PC ownership is more an indicator of wealth than of ICT competences. Nevertheless, the use of ICT has become so basic that it is hard to imagine that a person lacking basic ICT knowledge could attain higher education.

In most Western countries (and in many others as well) ICT is part of the curriculum of primary and/or secondary education. It is not a key course, but all students get an introduction to the most basic principles. As a consequence, the computer and the Internet have taken such an important place in the daily life of young people that most are connected with each other via SNSs (social networking sites), very often Facebook. There is no field of study in HE (higher education) where students can survive without any knowledge of ICT and without having a command of some basic ICT competences. Not only does the study of science need computers, but also the study of languages or of philosophy. It is obvious that science students will use more sophisticated ICT procedures than students of philosophy, but neither can study without a basic knowledge of computers and the Internet. Moreover, most major universities use a VLE (virtual learning environment, e.g., Blackboard) to support teaching and study. Research has shown that there is a wide range of ICT capabilities among university students (De Wit, Heerwegh \& Verhoeven, in press; Lee, 2003; Palaigeorgiou, Siozos, Konstantakis, \& Tsoukalas, 2005; Pillay, Irving, \& Tones, 2007; Verhoeven, Heerwegh, \& De Wit, 2010).

Since not all students are equally successful at university, we might question what types of knowledge of ICT and the Internet may contribute the most to success at university. For instance, in former articles (De Wit et al., in press; Verhoeven et al., 2010) we have already shown that first year students in the humanities are less competent than students in biomedical and other sciences with regard to using a spreadsheet to make graphs or perform calculations and with regard to using computers and the Internet for emailing. If ICT is important for educational attainment and if knowledge of ICT competences differs between different groups of students, then it makes sense to hypothesize that ICT competences may have differing influences on the achievements of students. Indeed, these competences may play a role in students' choice of a domain of study and may have consequences for the educational attainment of first year university students. Nelson Laird and Kuh (2005), for example, have shown that there is a relationship between the use of ICT in HE and active and collaborative learning on the one hand and the interaction between students and the faculty on the other. These findings bring us to the following research question: Taking into account some major explanatory variables (for instance, education of father and mother, GPA in secondary school, and intrinsic motivation), what do ICT capabilities and com- 
puter use contribute to the explanation of the educational attainment of first year university students?

We will answer this central question in four steps. First, we offer a short overview of the theories at the base of educational attainment. Second, the methodology of this research will be presented. Third, the results of this research will be shown, and fourth we present conclusions and offer some points for discussion.

\section{Theoretical Background}

Status and/or educational attainment have been subjects of research for many years. In the 1960s, the work of P. Blau and O.D. Duncan (1967), searching for an explanation of the occupational attainment of sons in the USA, was very influential. They constructed a theory in which the status attained by the sons was explained by referring to the education and occupational status of the fathers. During the same period, Sewell, Haller, and Portes (1969) developed a model in which not only the status differences but also the expectations of the actors (both fathers and sons) were included. Besides taking note of the occupational and educational attainment of actors, the researchers paid attention to the level of occupational and educational aspirations, the influence of significant others, the quality of academic performance in high school, the socio-economic status of the family, and the mental ability of the actors in high school. This was the starting point for a strong development of the study of occupational and educational attainment. Hundreds of papers have been devoted to this issue; too many to discuss here.

The large volume of research concerning educational attainment has resulted in researchers trying very different routes to answer the question of the determining factors. We will mainly refer to four projects, each dealing with different facets of the study of educational attainment.

When studying educational attainment it is very important to realize that it takes place in a particular social structure, where opportunities differ depending on the development of a community. Indeed, status attainment might develop very differently depending on the educational structure of a country, the wealth of a country, the support structure for education, the funding of higher education, the expectations regarding the tasks of parents, the expectations regarding children, etc. When students decide to register in a particular path of higher education, their chances are firstly determined by the possibilities offered by the society in which they live. Reflecting on some studies of educational attainment, this should not be forgotten.

In their book "Pathways to academic success in higher education", E. P. St. John and G. D. Musoba (2011) report variables that might have an influence on the level of educational attainment at university. The following explanatory variables are used: gender, ethnicity, family income, parents' level of education, school urbanicity, percentage of ethnic minority and impoverished students enrolling in secondary school, eligibility for a study grant, and whether a SAT (Scholastic Aptitude Test) was taken or not. Moreover, they include aspirations for post-secondary education, GPA (grade point average) of secondary school, class rank, prior testing, level of maths, science, history and English courses, type of literature course, foreign and classical languages, and type of high school. These variables are connected with the first step for students into HE, namely the SAT test. The researchers conclude that "students from higher income families and families with high levels of parent degrees attain higher SAT scores than students whose parents have only finished secondary school." The higher the SAT scores of these students the higher their aspirations. The most successful SAT scores are more usually attained by suburban students than those from an urban or a rural environment. High SAT scores were also attained by students who took advanced maths courses. This is not only the case for advanced maths courses, but for all other advanced courses in secondary school. 
The following variables were added to the model when examining persistence in a particular course of study during the first two years of HE: campus type and major in the freshman year. Once enrolled, changes of majors were explained using the former independent variables in addition to, among other items, remedial course work, enrolment status in first semester, the late enrolment indicator, and dependency status. Educational attainment is expressed here in the form of the persistence of a student. Persistence in education is influenced by the racial background of the students, the diploma type, and the grades in high school, and also by the parents' education and the high school preparation. For persistence at university, the achievement after the first year, together with the level of financial support, are also very important.

The study by S. Ou (2005) focused on the linkage between participation in early intervention programs and educational attainment. The study was based on two samples of children taken in 2002. One sample was of children who completed kindergarten and participated in a pre-school program to support problem children in the period from 1985 to 1986. The second comprised children with many similar characteristics (but also different ones), but who did not participate in the special program to improve their opportunities in school. The researcher examined whether this special program had some influence on the educational attainment of these children. Here, educational attainment was measured by the highest grade attained (at university and expressed by the number of credits earned) and completion of high school. The explanation of educational attainment was based on the study of five variables. First, cognitive advantage: this included a measurement of the cognitive skills of the children in kindergarten, grade retention, and achievements for maths and reading in eighth grade. Second, family support: parental involvement (positive) and recorded incidence of child abuse or neglect (negative). Third, social adjustment: teachers assessed the children in grades three and four with regard to their adjustment to the school. Fourth, motivational advantage: students in grades five, six and ten answered questions about their attitude towards studying. Fifth, school support: attention was paid to school quality and the number of times participants changed schools between grades four and eight (school mobility). Moreover, the researcher also included participation of the children in the special program. Three covariates were included in the research: gender, family risk status, and ethnicity. Based on former data and the analysis, attainment could best be predicted by cognitive advantage effects, family support, and school support. However, it was also shown that family, school, and personal factors (affected by the special program) might be important for the prediction of educational attainment. In comparison with former studies, this study showed that educational attainment is not only the result of the social position of a student, but that it can also be influenced by special programs organized in early childhood.

Van Bragt, Bakx, Bergen, and Croon (2011) did not use the concept "educational attainment," but focused on the study of outcome, measured as the attainment of required credits and study continuance. They constructed a model for analysis based on (1) personality characteristics, (2) personal orientations on learning, (3) study approach, and (4) former education. Five characteristics of personality were investigated: (1) extraversion, (2) agreeableness, (3) conscientiousness, (4) emotional stability, and (5) autonomy. Personal orientations on learning comprised the following characteristics: (1) constructive self-regulation, (2) reproductive external regulation, and (3) ambivalence and lack of regulation. The study approach was composed of two variables: (1) meaningful integrative approach (including information processing activities such as relating and structuring, and critical and concrete processing) and (2) superficial approach (containing memorizing and analyzing). These authors also stressed that the meta-analysis by Robbins et al. (2004) shows that college outcomes are better predicted by psychological and study skill factors than by socioeconomic status, standardized achievement, and the GPA in high school. Therefore, they opted for a model in which study outcome was examined taking into account personality characteristics, personal orientations on learning, study approach, and former education. Using the previously mentioned explanatory variables they concluded (1) that, contrary to observations by St. John and 
Musoba (2011), former education is not a good predictor for study outcome and (2) that credits and study continuance are predicted well by conscientiousness and also by ambivalence and lack of regulation. Students scoring high on conscientiousness and those scoring low on ambivalence will earn more credits and will be more likely to continue in higher education.

In a follow-up study of 7,656 graduates in the USA ten years after finishing tenth grade, Lleras (2008) concluded that "noncognitive behaviors are as important and perhaps more important than cognitive abilities (measured by achievement tests), in predicting individual educational and occupational success." Educational success was measured by referring to whether or not students graduated in the different levels of education. Non-cognitive behaviour was made operational using the following indicators: (1) answers of teachers to questions concerning the completion of homework by students, engagement of students in working for grades, tardiness of students, passivism of students, students' relations with other students, and frequency of disruptive behaviour of students in the classroom and (2) sum of the number of sports and of fine arts activities reported by the students in tenth grade.

These four projects (two concerning university graduates and two concerning educational attainment in the short period of time after attending kindergarten or secondary school) include a great variety of factors influencing educational attainment, such as social characteristics of students, parental socialization of students, early intervention programs, personality characteristics, and non-cognitive behaviour. However, these are certainly not the only factors. For instance, Robertson and Reynolds (2010) observed that human capital and parenting favourable to education support higher educational attainment. By analogy with St. John and Musoba (2011), we call this the academic pathways model or Model 1 (see Figure 1). What we did not find in existing literature was a study into the relevance of the ICT skills of students in respect of educational attainment. Nevertheless, there is no university nowadays where students can study without some knowledge of ICT.

The knowledge-based society in which these students live has put ICT in a key position. If students want to participate in this society and in life-long learning, they need to have the competence to use ICT tools to "search, evaluate, manage and use information." They need these competences to develop their personal knowledge and participate in organizational knowledge (Punie \& Ala-Mutka, 2007). Indeed, students are trained to become knowledge workers, and it would be hard (if not impossible) for them to work without the support of ICT (Schwartz, 2006). Knowledge management is very important for the realization of this knowledge-based society. Two main streams of knowledge management may be discerned: (1) organizational knowledge management and (2) personal knowledge management. Alavi and Leidner (2001, p. 114) define knowledge management systems as "... a class of information systems applied to managing organizational knowledge. That is, they are IT-based systems developed to support and enhance the organizational processes of knowledge creation, storage/retrieval, transfer, and application." In this definition knowledge management is defined as organizational knowledge management. Lytras and Pouloudi (2006) show that organizational knowledge is connected with personal knowledge, and other researchers place greater emphasis on the individual learner by using personal knowledge management (PKM) (Völkel \& Haller, 2009). Edwards, Ababneh, Hall, and Shaw (2009) define PKM as “... [the method by which] we, as individuals, manage our personal knowledge, and what tools, techniques and models can be developed to enhance our personal effectiveness and improve our lives as 'knowledge workers' in today's information society." PKM is not limited to making actors digital literates, but also encompasses learning of attitudes, social relations, knowledge about facts, etc. Nowadays Web 2.0 offers a lot of support for this process. Cigognini, Pettenati, and Edirisingha (2011) contend that university students are not well prepared to use Web 2.0 technologies and applaud teaching of PKM skills to university students. Based on qualitative research they developed a system to analyze the PKM basic skills and high- 
er-order PKM skills. Among the basic skills three macro-competency categories are discerned. Each of them cover specific PKM skills: "create" covers editing, integrating, editing etc.; "organize" refers to searching, finding, storing, etc.; and, "share" focuses on publishing, mastering knowledge exchange, etc. Four higher order PKM skills are mentioned: connectedness, "ability to balance formal and informal contexts", critical ability, and creativity. These researchers consider mastering the basic PKM skills as the first step for learning the higher-order PKM skills. However, in this research we contend that before a learner can learn what has been called "basic PKM skills" for Web 2.0, even more basic ICT skills have to be mastered, like sending emails, using search engines, creating accounts on SNS, etc. (see in Figure 1 the personal knowledge model). They contribute to the creation, organization, and sharing of personal knowledge, but are not identical to the skills of Web 2.0. Moreover, we will study the meaning of ICT skills in connection with the place of the student in society. Personal knowledge management is related to the social situation of the actor and this means that the study of the meaning of ICT skills for education attainment should be analyzed in connection with the social position of the actor. To do this we will rely on the information collected for the academic pathways model

\begin{tabular}{|c|c|}
\hline Predictor variables & Dependent variables \\
\hline $\begin{array}{l}\text { Model 1: Academic } \\
\text { pathways model } \\
\text {-Higher education of mother } \\
\text { (1) or not ( } 0 \text { ) (dummy } \\
\text { variable) } \\
\text {-Higher education of father } \\
\text { (1) or not ( } 0) \text { (dummy } \\
\text { variable) } \\
\text {-Financial comfort } \\
\text {-female (1) or male ( } 0) \\
\text { (dummy variable) } \\
\text {-GPA of secondary school } \\
\text {-6 or more hours for maths in } \\
\text { secondary school (1) or less } \\
\text { (0) (dummy variable) } \\
\text {-Classical languages (1) or } \\
\text { not (0) (dummy variable) } \\
\text {-Scholarship (1) or not }(0) \\
\text { (dummy variable) } \\
\text {-Humanities and social } \\
\text { sciences ( } 1 \text { ) or not }(0) \\
\text { (dummy variable) } \\
\text {-Ambivalence } \\
\text {-Intrinsic motivation } \\
\text {-Engagement in social } \\
\text { activities ( } 1 \text { ) or not }(0) \\
\text { (dummy variable) } \\
\text {-Reading }\end{array}$ & $\begin{array}{ll}\text { - } & \text { Persistence of study } \\
& \text { choice } \\
\text { - } & \text { Study efficiency } \\
\text { - } & \text { GPA }\end{array}$ \\
\hline $\begin{array}{l}\text { Model 2: Personal } \\
\text { knowledge management } \\
\text { model } \\
\text { All predictors of model 1, } \\
\text { plus: } \\
\text {-Social contact skills } \\
\text {-Basic ICT skills } \\
\text {-Maintenance skills }\end{array}$ & $\begin{array}{ll}\text { - } & \text { Persistence of study } \\
\text { choice } \\
\text { - } & \text { Study efficiency } \\
\text { - } & \text { GPA }\end{array}$ \\
\hline
\end{tabular}

Figure 1. Explanatory models 
There is much research showing that knowledge about ICT or the use of ICT in classrooms can improve some or all of the achievements of students, although little is known about the relation between the knowledge of ICT skills among students and their education attainment. Most of this research is focused on technology-enhanced classrooms, CAI (computer assisted instruction), elearning interventions, and the like. The achievements of students are seen as a result of the support coming from ICT-aware teachers or school organization (Bell, 2007; Carle, Jaffee, \& Miller, 2009; Pedro, 2005; Qayumi et al., 2004; Vernadakis, Antoniou, Giannousi, Zetou, \& Kioumourtzoglou, 2011). That this is not always true is confirmed by Svirko and Mellanby (2008). They observed lower levels of deep learning in a CAL (computer-aided learning) course for medical students than for other courses. If we connect all these findings with those of E. Hargittai (2010), namely that the socioeconomic status of students is an important predictor for incorporating the Web into daily life, it makes sense to question the relationship between ICT competences and computer and ICT use with regard to educational attainment.

The link between ICT and achievement is not only shown in research about CAI and e-learning, but also about ICT knowledge and dedication to using computers. Tien and Fu (2008) demonstrated that ICT knowledge and the use of computers for academic work have a moderate effect on the achievement of university students. Mainly the software knowledge of students was shown to be a good predictor for achievement.

This is also true for computer ownership. Schmitt and Wadsworth (2006) concluded that computer ownership is a positive factor for the study achievements of secondary school students in the UK. George, Dixon, Stansal, Gelb, and Pheri (2008) also made the same observation with regard to the GPA of Canadian university students. These authors are aware that computer ownership can be seen as a proxy of socioeconomic status. The boom in the availability of laptops led to the assumption that computer use would increase and would therefore contribute to a rise in the GPA of students with a laptop. However, Wurst, Smarkola, and Gaffney (2008) did not find evidence for this hypothesis in a study at an American university. But computer ownership does not tell much about ICT skills of the owner.

Although former projects support the suggestion of a positive effect of CAI on the achievements of many students, several authors stress that research on this subject is currently inconclusive. Moreover, not all results are positive. Şendag and Odabaşi (2009) concluded that undergraduate students who took an online, problem-based computer course did not benefit from a significant gain to their content knowledge acquisition scores, but on the other hand their critical thinking skills were improved. Hunley, Evans, Delgado-Hachey, Krise, Rich, and Schell (2005) did not find a significant correlation between computer use and GPA among high school students in Ohio.

Taking into account that universities assume students have at least basic knowledge of the use of computers and the Internet, it is important to question the contribution of this knowledge to educational attainment. Moreover, although not univocal, literature shows that teaching supported by ICT instruments might have an influence on educational attainment. In order to check whether ICT competences have some influence on educational attainment we develop two models. One will take into account the traditional variables which have been used for many years to explain educational attainment. This is the academic pathways model. A second model will examine to what extent ICT competences, together with the social background of a student, might improve predictions of educational attainment. Although this model contains more than the process of personal knowledge management, it will be called the personal knowledge management model or Model 2. 


\section{Methodology}

To answer the research question, we initiated a study at a large university (with about 35,000 students of whom about 5,000 are foreigners, most of them graduate students). The university has a long tradition and is situated in a small, Belgian town. Most students live in rooms in the private rental sector and a smaller number live in university dormitories or at home. Almost all students have access to a high-speed broadband connection, and in many buildings of the university numerous PCs are continuously available. Moreover, a lot of wireless 'hotspots' provide ready connection to the Internet. This university also uses a digital learning platform, which suggests the assumption that students have at least a basic knowledge of computer and Internet use.

Data was collected among all registered freshmen $(\mathrm{N}=5,448)$ in October and November 2009 using an online questionnaire which produced 1,529 responses. To check the quality of the sample, the sample distribution of several important parameters was compared with the population distribution (known from the enrolment records which are available for all enrolled students). These parameters were age and secondary school of the students, employment and employment type of the parents (four characteristics), education of the father and mother, scholarship of the student, housing of the student, domain of study of the student, and participation in the university introduction day. Most distributions of the sample did not differ significantly from the distributions of the population except three: gender, housing and field of study. All presented analyses use a weighting variable to correct for these discrepancies.

In order to answer our research question we applied the models described in Figure 1.

In the first of two steps, we will check the extent to which the traditional explanatory variables of the academic pathways model can predict the educational attainment of freshmen (Lleras, 2008; Scherger \& Savage, 2010; St. John \& Musoba, 2011). In the second step, the personal knowledge management model, the analysis will include the variables of former model completed by ICT competences in order to determine whether these contribute to the prediction of educational attainment and if so, to what extent. The results will be obtained by using linear regression analysis. At the end of each step we will check whether our models have different consequences for humanities and social science students on the one hand and for biomedical and science students on the other. Therefore a regression analysis, using the same explanatory variables of Model 1 and Model 2, will be applied on the subsample of humanities and social science students and of (biomedical) science students.

\section{Dependent Variables}

Three indicators are used for measuring the educational attainment of freshmen. Educational attainment will be expressed in terms of the persistence of study choice at the end of the academic year, the attained study efficiency at the end of the academic year, and the GPA (Grade Point Average) at the end of the academic year. These indicators are further explained below.

Persistence of study choice (PS) has three levels:

$\mathrm{R}=$ registered (score 3 ): students who registered in the same domain of study during the first and second academic years;

$\mathrm{RO}=$ reoriented (score 2): students who left their original domain of study chosen at the beginning of the first academic year but continued the new domain in the same university in the second academic year;

$\mathrm{DO}=$ dropouts (score 1): students who left the university in the first or second year. 
Study efficiency (SE): the proportion of exams for which the student attained a satisfactory grade at the end of the year. Calculated as the number of exams passed at the end of the academic year divided by the number of exams that the student should have taken.

The GPA is expressed as the average percentage attained by a student on all the exams he or she had to take in one academic year.

\section{Independent Variables}

In order to check the two theoretical models we use two categories of independent variables. The first category contains most of the traditional variables that might influence educational attainment. The second category includes three variables describing the ICT competences of the students.

The first category of variables is based on research detailed in the section "Theoretical background." This research has shown that some variables frequently have an important impact on educational attainment. We selected 13 of these variables, most of which show a positive influence on educational attainment. We will check whether this is also true for the freshmen involved in this study.

These are the variables that are included in the academic pathways model:

Education level of mother (HEMoth) (dummy variable). Coded 1 for students whose mother possessed a college or university diploma, coded 0 for other students.

Education level of father (HEFath) (dummy variable). Coded 1 for students whose father possessed a college or university diploma, coded 0 for other students.

Financial comfort: for the question: "Is your parents ' position financially difficult?" students could answer: very difficult ( $($ core $=6$ ), rather difficult (score $=5)$, difficult (score $=4)$, easy $($ score $=3)$, rather easy ( score $=2)$, and very easy ( score $=1)$.

Gender (dummy variable): Coded 1 for female students and 0 for male students.

GPA in secondary school: achievement expressed as a percentage of the total possible exam results.

Maths (dummy variable) $=$ number of hours spent on the study of maths every week in the last grade of secondary school: 5 or less hours a week $($ score $=0)$; six or more hours a week (score $=$ $1)$.

Classical languages $($ dummy variable $)=$ did not study classical languages $($ score $=0)$ or did $($ score $=1)$.

Scholarship: if the parents of a student have a lower annual income than a particular level determined by the government, the student can apply for a scholarship which does not have to be repaid. This support is meant for the less wealthy students. Students with a scholarship scored 1, other students scored 0 (dummy variable).

Domain of study: we restrict the analysis to the difference between humanities and social sciences students (score $=1$ for the dummy; humanities and social sciences) and other students (score $=0$; science and biomedical science students).

The ambivalent attitude of a student toward study choice: this scale was developed by Vermunt (1994) and contains following items: "I doubt whether this is the right subject area for me"; "I have little confidence in my study capacities"; "I wonder whether these studies are worth all the effort"; "I doubt whether this type of education is the right type of education for me"; "I am 
afraid these studies are too demanding for me". Factor analysis of our data confirmed this Likerttype scale (Cronbach's $\alpha=0.81$ ) (De Wit et al., in press).

Intrinsic motivation: students had to place themselves on a scale from 1 to 4 assessing two statements:

- "I am motivated to study because I am highly interested in studying";

- "I am motivated to study because studying is a pleasant experience".

These items are part of a selection of eight items (out of 16) concerning study motivation (Van Steenkiste, Sierens, Soene, Luyckx, \& Lens, 2009). A factor analysis (promax rotation) detected four factors. One of them is composed of the former two items (standardized regression coefficients are respectively 0.80 and 0.83 ; Cronbach's $\alpha=0.82$ ).

Engagement in social activities (dummy variable): students were asked the following question: "Apart from your studies, to what extent are you engaged in student, sports or youth clubs, or other social or cultural activities?" Scores: none $=0$; engaged in social activities $=1$.

Reading books: students had to answer the question: "During the previous academic year how often did you read a book?" (Score between 1 and 7, beginning with "almost none" (score =1) and finishing with "several books a week" (score $=7$ ).

Visit to library: students had to answer the question: "On average during the previous academic year how often did you visit a library?" (Score between 0 and 6, beginning with "never" (score = 0 ) and finishing with "several times a week" $($ score $=6)$ ).

The last two variables are combined into the variable "Reading", with scores between 0 (almost no books were read nor a library visited) and 6 (during a week several books were read and a library was visited more than once).

In addition to the independent variables of Model 1, the personal knowledge management model includes three variables describing the ICT competences of the students. ICT competences were observed by asking students to assess their own competences for 21 different ICT skills (see Table 1) on a scale of 1 ("this is totally not true for me") to 5 ("this is totally true for me"). Most items were suggested in work by Van Braak (2004), but have been expanded with some items referring to the use of social networking sites (SNSs). An attempt to empirically find in our data the same categories (based on qualitative research), described by Cigognini, Pettenati and Edirisingha (2011) for the analysis of Web 2.0, was not successful. Some items did not find a place in these categories, and some others were linked with other categories than was suggested by these researchers.

Using an exploratory factor analysis (EFA, ULS method) with Mplus 4.0, three types of skills were found: social contact skills (Factor 1) (Cronbach's $\alpha=0.83$ ), basic ICT skills (Factor 2) (Cronbach's $\alpha=0.77$ ), and maintenance skills (Factor 3) (Cronbach's $\alpha=0.80$ ). Factor 1 contains ICT skills such as attaching a file to an email, using a search engine, etc. Factor 2 refers to skills such as working with spreadsheets, making table contents, and the like. Factor 3 represents the skills necessary to keep a computer functioning properly. The RMSR (standardized root mean square residual) is 0.0327 and indicates a good model fit since it is lower than .05 (Vandenberg \& Lance, 2000). It is not unreasonable to suggest that students who are more familiar with these ICT skills may have more time for study than those who are less skilled, and they consequently score higher for education attainment. 
Table 1. Average scores and standard deviations of self-perceived ICT competences (2009) and Promax rotated loadings of an explorative factor analysis for the construction of three types of ICT competences (factor loadings $>-.25$ and $<.25$ not included in the scales are omitted) (score 1 to 5)

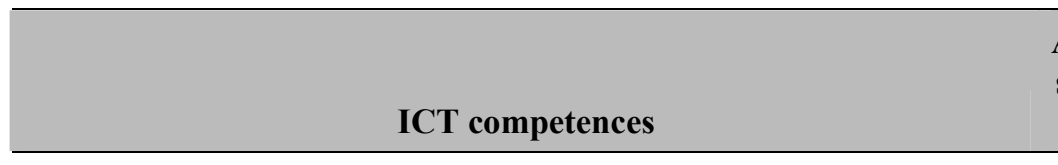

3) I can attach a file to an email.

15) I can search for web pages on the Internet using a search engine (e.g. Google, AltaVista, Botje, etc.).

9) I can talk to someone using a chat program (e.g. Messenger, IRC, etc.).

11) I can prepare a short lecture or presentation using a presentation program (e.g. PowerPoint).

20) I can create an account on social networking sites (e.g. Facebook, Netlog, Twitter, etc.).

21) I can manage an account on social networking sites (e.g. Facebook, Netlog, Twitter, etc.).

18) I can play a computer game myself.

13) I can upload and download files using a web browser (e.g. Internet Explorer, Netscape, etc.).

1) I can use the automatic spellchecker.

14) I can make bookmarks or favourites with a web browser (e.g. Internet Explorer, Netscape, etc.).

16) I can change the resolution of my monitor myself.

17) I can connect a computer and install software myself.

19) I can install my virus scanner myself (e.g. McAfee, Norton, etc.).

6) I can make a graph in a spreadsheet program (Excel, Lotus, etc.).

7) I can make simple calculations in a spreadsheet program (Excel, Lotus, etc.).

12) I can organise files on a computer using a file manager (e.g. Explorer).

2) I can make a back-up or reserve copy of data on my hard disk.

8) I can automatically make a table of contents for a report with a word processor.

5) I can create a new, simple database and put in data using database software (e.g. Access).

10) I can create my own home page using web design software (e.g. FrontPage, Dreamweaver, etc.).

4) I can publish a website on the Internet (FTP).

\begin{tabular}{|c|c|c|c|c|}
\hline $\begin{array}{c}\text { Average } \\
\text { score in } \\
2009\end{array}$ & $\begin{array}{l}\text { Std } \\
\text { Dev }\end{array}$ & $\begin{array}{c}\text { Factor } \\
1\end{array}$ & $\begin{array}{c}\text { Factor } \\
2\end{array}$ & $\begin{array}{c}\text { Factor } \\
\mathbf{3}\end{array}$ \\
\hline 4.86 & 0.43 & 0.83 & & \\
\hline 4.86 & 0.43 & 0.86 & & \\
\hline 4.84 & 0.53 & 0.91 & & \\
\hline 4.76 & 0.58 & 0.71 & & \\
\hline 4.72 & 0.68 & 0.78 & & \\
\hline 4.65 & 0.77 & 0.72 & & \\
\hline 4.60 & 0.79 & & & \\
\hline 4.59 & 0.76 & & & \\
\hline 4.47 & 0.87 & & & \\
\hline 4.36 & 1.01 & & & \\
\hline 4.28 & 1.10 & & & 0.72 \\
\hline 4.01 & 1.27 & & & 0.89 \\
\hline 3.99 & 1.22 & & & 0.89 \\
\hline 3.96 & 1.13 & & 0.91 & \\
\hline 3.94 & 1.11 & & 0.94 & \\
\hline 3.78 & 1.36 & & & 0.46 \\
\hline 3.67 & 1.36 & & & 0.56 \\
\hline 3.32 & 1.37 & & 0.47 & \\
\hline 2.73 & 1.33 & & 0.52 & \\
\hline 2.32 & 1.36 & & & \\
\hline 2.28 & 1.33 & & & \\
\hline
\end{tabular}




\section{Results}

\section{ICT Skills and Access to Computers and the Internet}

If we expect that mastering ICT skills will increase the opportunities for freshmen to attain a particular level of education, it is clear that computers and the Internet should be accessible to them. This is more necessary now than, for example, ten years ago. The current position of modern universities is that they use a virtual learning environment daily, ask students to search on the Internet for data, and ask them to write papers and give PowerPoint presentations. Libraries are computerized and confront readers with huge data banks which students have to use to find what they need for their studies. More and more special digitalized teaching programs are becoming part of daily student life. In this environment it is no longer sufficient for a student to know how to read and write a paper, but also necessary for them to know all the techniques to read digitalized sources and, further, know how to communicate using digital technology. For all of this, it is essential that students have access to the instruments needed to collect the necessary sources, write papers, communicate and discuss with lecturers and other students, present the results of their research, etc. In this context, a computer is necessary.

Although this university offers PCs in many places that can be used by students for free, it is expected that students have access to a computer at the place where they study. In $2009,65 \%$ of the freshmen had a PC for their sole use at home in their own room, 34\% shared a computer with other members of the family, and 1\% had no PC at home. $99 \%$ of the students living in the university town had a PC and about $1 \%$ of the students had to share a computer or did not have a PC. At the university $94 \%$ of the students used laptops, whereas at home this figure was only $60 \%$.

Computers are important for students, but a link to the Internet is no less important. It is by working on the Internet that students can search for information and communicate with teachers and colleagues. In 2009, almost all students had a connection to the Internet at home. $90 \%$ of them had broadband Internet access, $2 \%$ had a connection that was charged according to the time the Internet was used, and 8\% did not know what kind of connection was used. $98 \%$ of the students living in the university town had a broadband connection, and $2 \%$ did not know what kind of connection they had.

Students did not arrive unprepared for using the Internet at university. In their final grade of secondary school, about $96 \%$ of the freshmen used a computer for their study once a week or more and $35 \%$ used a computer daily. Nevertheless, the school was not the most important place for using a computer for study. Only $3 \%$ of the students used a computer for study mostly in school, but $95 \%$ used a computer at home. In the final grade of secondary school the majority $(92.5 \%)$ did not attend any classes in information technology, $5 \%$ received one hour a week, and a very small proportion of the students received more hours a week.

Nevertheless, students frequently used computers for some tasks. Table 2 shows that during the year before the survey, $87 \%$ of students surfed the Internet daily, $69 \%$ sent emails daily, and 59\% searched for information on the Internet daily. Even those who did less score very high. On a scale of 1 to 6 , students attained a score of 5.82 for surfing on the Internet, 5.57 for emailing and 5.46 for searching on the Internet. Chatting was also very popular: $44 \%$ were chatting daily and the average score was 4.75. Less popular were downloading pictures or music, participating in newsgroups on the Internet, and mailing messages to forums. But in spite of these lower scores, it is clear that most freshmen had daily contact with a computer and the Internet (see also Bruneel, De Wit, Verhoeven, \& Elen, 2011). 
Table 2. Self-perception of computer and Internet use in 2009 (\% and average score (1 to 6$)$ )

\begin{tabular}{|c|c|c|c|c|c|c|c|c|}
\hline Computer used for & $\begin{array}{c}\text { Daily } \\
\%\end{array}$ & $\begin{array}{c}2 \text { or } 3 \\
\text { times a } \\
\text { week } \\
\%\end{array}$ & $\begin{array}{c}\text { Weekly } \\
\%\end{array}$ & $\begin{array}{c}\text { Monthly } \\
\%\end{array}$ & $\begin{array}{c}\text { Less than } \\
\text { once a } \\
\text { month } \\
\%\end{array}$ & $\begin{array}{c}\text { Never } \\
\%\end{array}$ & $\begin{array}{c}\text { Total } \\
\%\end{array}$ & Score \\
\hline Surfing the Internet & 87.3 & 9.3 & 2.5 & 0.1 & 0.4 & 0.4 & 100.0 & 5.82 \\
\hline Emailing & 69.1 & 21.0 & 8.2 & 1.2 & 0.4 & 0.1 & 100.0 & 5.57 \\
\hline $\begin{array}{l}\text { Searching on the Inter- } \\
\text { net }\end{array}$ & 58.8 & 29.6 & 10.1 & 1.0 & 0.4 & 0.1 & 100.0 & 5.46 \\
\hline Chatting on the Internet & 44.4 & 21.7 & 15.0 & 6.6 & 7.8 & 4.5 & 100.0 & 4.75 \\
\hline $\begin{array}{l}\text { Downloading music or } \\
\text { pictures from the Inter- } \\
\text { net }\end{array}$ & 15.2 & 14.0 & 17.6 & 19.0 & 18.6 & 15.6 & 100.0 & 3.42 \\
\hline $\begin{array}{l}\text { Participating in news- } \\
\text { groups on the Internet }\end{array}$ & 7.1 & 7.6 & 11.1 & 9.7 & 30.3 & 34.2 & 100.0 & 2.49 \\
\hline $\begin{array}{l}\text { Mailing messages to a } \\
\text { forum }\end{array}$ & 8.4 & 9.2 & 10.9 & 12.5 & 33.4 & 25.6 & 100.0 & 2.70 \\
\hline
\end{tabular}

Because freshmen very frequently use computers and the Internet, it is not surprising that students score points as far as their self-perception of ICT competences is concerned. Of the 21 ICT competences mentioned in Table 1, eleven competences attain a score higher than 4 out of 5 . This means that students think they have good knowledge of how to attach a file to an email, how to use a search engine, how to use a chat program, how to make a PowerPoint presentation, how to create and manage an account on a SNS (social networking site), how to play a computer game, how to load files using a web browser, how to automatically check the spelling of a text, how to store bookmarks or favourites with a web browser, how to change the resolution of a monitor, and how to connect a computer and install software. We find lower scores, but still above the midpoint 3 , for the capabilities of installing a virus scanner, producing graphics or carrying out calculations with a spreadsheet program, organising files with a file manager, making a back-up on a hard disk, and automatically generating a content table with a word processor. Less popular (less than a score of 3 out of 5) is creating a database with database software, creating a home page with web design software, or publishing a website on the Internet. We can state that freshmen know most of the tricks for carrying out most tasks on the Internet, but most of them do not know how to create a home page on the Internet.

For further analysis in this article, using factor analysis (see the section "Independent variables") three categories of ICT competences were constructed. Among these categories, the highest score is found for social contact skills ( score $=4.78$ out of 5; Std Dev $=0.43$ ). The second highest score is 3.95 for maintenance skills ( $\mathrm{Std}$ Dev $=0.94$ ), and this is followed by basic ICT skills (score $=$ 3.49; Std Dev = 0.96). Because social contact skills have a very high score and a rather small standard deviation, it may be expected that this category will not show much differentiation. These skills are so widespread among freshmen that it is hard to show a difference between them based on this information.

\section{Academic Pathways Model and Educational Attainment}

Depending on the instrument used for measuring educational attainment, the academic pathways model or Model 1 can explain 12\% to 34\% of the variance in educational attainment. 
Model 1 is the least powerful for explaining persistence of study choice. After one year of study at university, $73 \%$ of the students were registered in the same domain of study as in the first year, $9 \%$ left the domain of study initially chosen but continued at the same university, and $18 \%$ dropped out and left university. The two best predictors in this model are the number of hours spent by a student in secondary school studying mathematics $(b=0.18)$ and the ambivalent attitude of students toward their study choice $(b=-0.15)$. The more hours of maths a student attended in the last year of secondary school, the more likely it is that he or she will register in the same domain of study for the first and second years at university. This is the opposite for students scoring high on the ambivalence scale for study choice. If students are not sure that they chose the right path, they are more likely to drop out of university or choose another domain of study. Two other useful predictors are found in the GPA in secondary school $(b=0.12)$ and having studied classical languages in secondary school $(b=0.12)$. Persistence of study is significantly higher for students with a high GPA and those who studied classical languages. This is also true for students living in a family where the mother attended higher education $(b=0.06)$ and among humanities and social sciences students $(b=0.08)$.

No predictive power for persistence of study choice was found in families where the father attended higher education. Further, as far as persistence of study choice is concerned, no differences were found between male and female students, between students with a scholarship and those without, or between students whose parents felt financially comfortable and those who did not. The intrinsic motivation of the students does not matter for the persistence of study choice, and neither does their reading behaviour and their engagement in social activities.

The academic pathways model is clearly stronger for explaining study efficiency (adj. $\mathrm{R}^{2}=0.27$ ) than for persistence of study choice (adj. $\mathrm{R}^{2}=0.27$ ) (see Table 3 ). The most powerful predictor here is the GPA in secondary school $(b=0.32)$, followed by the number of hours spent studying maths in secondary school $(b=0.24)$, the study of classical languages in secondary school $(b=$ $0.13)$, and ambivalent feelings about the study choice $(b=-0.12)$. The first three variables predict a higher study efficiency when the student scores higher on each of them. The last predicts a lower study efficiency when the student has more ambivalent feelings about his or her study choice.

As is the case for the explanation of the persistence of study choice, we observe that when the mother has attended higher education $(b=0.07)$ or when the student studies humanities or social sciences $(b=0.07)$, it is more likely that their study efficiency is higher than that of students whose mother did not attend higher education or those studying (biomedical) sciences. This is also true when students are intrinsically motivated to study $(b=0.05)$.

Contrary to what could be expected from the study by Scherger and Savage (2010), i.e., that reading books could have a positive effect on study efficiency, our data stresses that the more books students read and the more often they visit a library, the lesser the result they will achieve for study efficiency at the end of the first academic year $(b=-0.10)$. This observation needs some clarification. First, Scherger and Savage did not ask how many books respondents had read, but actually asked "how much did they encourage you to... reading books 'that were not required for school and religious studies". This question is more about the encouragement to read books than about actually reading them. Second, Scherger and Savage posed this question to a large sample, comprising people from 16 years of age upwards, whereas in our sample only freshmen were interviewed. As we have shown in the section "Methodology," our question did not specify the types of books or libraries. Nevertheless, our data shows that the more time students spend in a library or reading books, the more likely it is that they will have a lower study efficiency score. We will see that this statement is confirmed with regard to the GPA for the first year in the university and in Model 2. We will come back to this observation later in the discussion. 


\section{Table 3. Traditional explanatory variables and ICT competences as predictors of persistence of study, study efficiency, and achievement (linear regression analysis; standardized parameters).}

\begin{tabular}{|c|c|c|c|c|c|c|}
\hline \multirow[t]{2}{*}{ Predictors } & \multicolumn{3}{|c|}{ Academic pathways model } & \multicolumn{3}{|c|}{ Personal knowledge management model } \\
\hline & $\begin{array}{l}\text { Persistence } \\
\text { of study } \\
\text { choice }\end{array}$ & $\begin{array}{l}\text { Study effi- } \\
\text { ciency }\end{array}$ & GPA & $\begin{array}{l}\text { Persistence } \\
\text { of study } \\
\text { choice }\end{array}$ & $\begin{array}{l}\text { Study effi- } \\
\text { ciency }\end{array}$ & GPA \\
\hline Intercept & 0 & 0 & 0 & 0 & 0 & 0 \\
\hline HEMoth & $0.06^{*}$ & $0.07 *$ & $0.06^{*}$ & - & $0.06^{*}$ & $0.05^{*}$ \\
\hline HEFath & - & - & $0.06^{*}$ & - & $0.06^{*}$ & $0.07 * *$ \\
\hline $\begin{array}{l}\text { GPA secon- } \\
\text { dary }\end{array}$ & $0.12 * * *$ & $0.32^{* * *}$ & $0.37 * * *$ & $0.14 * * *$ & $0.30^{* * *}$ & $0.36^{* * *}$ \\
\hline Maths & $0.18 * * *$ & $0.24 * * *$ & $0.24 * * *$ & $0.18^{* * *}$ & $0.24 * * *$ & $0.25 * * *$ \\
\hline Classical & $0.12 * * *$ & $0.13^{* * *}$ & $0.14 * * *$ & $0.11 * * *$ & $0.11 * * *$ & $0.12 * * *$ \\
\hline Female & - & - & - & - & - & - \\
\hline $\begin{array}{l}\text { Financial com- } \\
\text { fort }\end{array}$ & - & - & - & - & - & - \\
\hline Scholarship & - & - & - & - & - & - \\
\hline $\begin{array}{l}\text { Humanities } \\
\text { and social sci- } \\
\text { ences }\end{array}$ & $0.08 * *$ & $0.07 *$ & - & $0.07 * *$ & - & - \\
\hline Ambivalence & $-0.15 * * *$ & $-0.12 * * *$ & $-0.11 * * *$ & $-0.16^{* * *}$ & $-0.14 * * *$ & $-0.13 * * *$ \\
\hline $\begin{array}{l}\text { Intrinsic moti- } \\
\text { vation }\end{array}$ & - & $0.05 *$ & $0.07 * *$ & - & $0.06^{*}$ & $0.08 * * *$ \\
\hline Reading & - & $-0.10 * * *$ & $-0.08 * * *$ & - & $-0.08 * * *$ & $-0.06^{* *}$ \\
\hline Engagement & - & - & - & - & - & - \\
\hline $\begin{array}{l}\text { Social contact } \\
\text { skills }\end{array}$ & - & - & - & - & - & - \\
\hline $\begin{array}{l}\text { Basic ICT } \\
\text { skills }\end{array}$ & - & - & - & - & - & $-0.06^{*}$ \\
\hline $\begin{array}{l}\text { Maintenance } \\
\text { skills }\end{array}$ & - & - & - & $-0.09 * *$ & $-0.11 * * *$ & $-0.12 * * *$ \\
\hline Adj $R^{2}$ & 0.12 & 0.27 & 0.34 & 0.13 & 0.28 & 0.36 \\
\hline $\mathrm{F}$ & $15.07 * * *$ & $36.87 * * *$ & $51.69 * * *$ & $13.12 * * *$ & $31.70 * * *$ & $44.49 * * *$ \\
\hline
\end{tabular}

Study efficiency is not influenced by the level of higher education of the father, the gender of the student, the financial comfort of the parents, the scholarship of the student, or the engagement of the student in social activities.

The best prediction of Model 1 is shown when looking for the prediction of the GPA for the first year at the university (adj. $\mathrm{R}^{2}=0.34$ ) (see Table 3 ). In line with the observations concerning study efficiency, the GPA for the first year at the university can best be predicted by referring to the GPA in secondary school $(b=0.37)$, the number of hours studying maths in secondary school 
$(b=0.24)$, and having studied classical languages $(b=0.14)$. Students whose father $(b=0.06)$ or mother $(b=0.06)$ attended higher education or students who are intrinsically motivated $(b=0.07)$ also obtain a higher GPA at university than other students. High ambivalent feelings about the choice of study $(b=-0.11)$ and the more students read books and visit libraries $(b=-0.08)$ are associated with a lower GPA at the end of the first year.

Gender differences, financial comfort, scholarship, and engagement in social activities do not contribute to a better prediction of the GPA at the end of the first year at university.

Often it is hypothesized that students taking classical languages in secondary school are better prepared for studying successfully humanities and that students with a strong maths program are better prepared for (biomedical) sciences. To check this hypothesis we applied model 1 separately on humanities and social science students and on biomedical and science students. First, we saw that our model explained almost the same variance for both samples (Adj. $\mathrm{R}^{2}$ is between 0.12 and 0.34). Second, both the study of classical languages and a substantial maths program in secondary school are significant predictors for the three measures of educational attainment, except for the prediction of the persistence of study among biomedical and science students. For the latter, having taken a substantial maths program is a good predictor $(b=0.18 ; \mathrm{p}<0.0001)$, studying classical languages in secondary school is not. Third, having taken a serious math program in secondary school is a better predictor for education attainment of biomedical and science students as well as humanities and social science students than classical languages in secondary school, except for the prediction of the persistence of study choice of humanities and social science students. In this case classical languages $(b=0.15 ; p<0.0001)$ predict more persistence than the study of mathematics $(b=0.14 ; p=0.0001)$.

\section{Personal Knowledge Management Model and Educational Attainment}

The personal knowledge management model brings us to the kernel of our research question: does the fact that a student has more command of ICT skills contribute to a better prediction of his or her educational attainment? If students do not have any idea of how to work with a word processor, a spreadsheet, a web browser, etc., it will be hard for them to use a virtual learning environment, complete assignments, search on the Internet, etc. Moreover, more and more forms of CAI are being introduced into classrooms, and here students are also supposed to have a certain level of ICT skills. Nevertheless, we have to stress here that our research is not about the consequences for freshmen of using CAI, but about the contribution of the command of ICT competences to their achievements, in other words, the contribution of the most basic characteristics of the personal knowledge management model. If it is true that a student has to know how to work with computers and the Internet to meet the expectations of lecturers, it makes sense to examine whether a better knowledge of these ICT competences might help to improve the prediction of the educational attainment of freshmen. As described in the section "Independent variables," we differentiate between three forms of ICT competences: social contact skills, basic ICT skills, and maintenance skills. In the analysis of Model 1 it has been shown that some variables do contribute to the prediction of educational attainment in its different forms. We will proceed by determining whether, in addition to some of the variables from Model 1, ICT competences contribute to a better explanation of educational attainment and how large this contribution is.

The ICT skills of the personal knowledge management model do not have a great influence on the explanation of educational attainment as examined in its three forms: the adj. $\mathrm{R}^{2}$ for persistence of study choice is 0.13 , for study efficiency 0.28 , and for GPA at the end of the first year at university it is 0.36 . 
The predictors for the persistence of study choice in Model 2 are almost the same as in Model 1 , except that the education level of the mother does not have a significant influence anymore and that the level of maintenance skills of the student allows improvement of the prediction (see Table 3). The best predictors are the number of hours a student attended maths classes in the last year of secondary school $(\mathrm{b}=0.18)$ and the level of ambivalent feelings a student has about their study choice $(b=-0.16)$. The higher the number of maths hours in secondary school the more persistent the student will be, but more ambivalent feelings about study choice are associated with less persistence in the chosen study.

A higher GPA in secondary school $(b=0.14)$, having studied classical languages in secondary school $(b=0.11)$, or being a humanities or social sciences student $(b=0.07)$ positively affect the persistence of study choice. But, contrary to our expectations, the command of social contact skills or basic ICT skills do not impact on the persistence of study choice, and students with high maintenance skills seem to be less persistent in their study choice $(b=-0.09)$. This finding needs some explanation.

As was previously suggested, it could be expected that the very high average score for social contact skills (4.78 out of 5) with a rather small standard deviation ( 0.43$)$ would not allow much differentiation between students. This is not the case for basic ICT skills and maintenance skills. Nevertheless, persistence of study choice among students seems not to be influenced by their command of basic ICT skills. It is also peculiar that students who are capable of maintaining a computer are less persistent in following their study choice. It seemed to us an acceptable hypothesis that students who are capable of changing the resolution of a computer monitor, know how to install software or a virus scanner, and know how to make a back-up to a hard disk would also be more capable of persisting in their chosen study. Indeed, students with these ICT competences have at least some of the basic skills necessary to manage their personal knowledge. Nevertheless, the observed parameter $(b=-0.09)$ gives a different message. A plausible explanation for this unexpected finding could be that although computers and the Internet are necessary work instruments for a student at university, they are not necessary for studying and taking exams sensu stricto. Basically, in respect of the content of most courses, students will be able to understand what a lecturer teaches without the use of a computer or the Internet, notwithstanding the fact that knowledge of computers and the Internet might be necessary in a practical sense in order to search for additional information, make presentations, etc. This might have as a consequence that students realise it is not necessary to know everything about the functioning of a computer in order to be able to use it. Above, it has been shown that computers and the Internet are frequently used for particular tasks. Although we do not know whether the use of computers and the Internet are for study or just for fun, there are reasons to believe that the daily use of a computer by students is more for relaxation than for study. Moreover, in a research by Bruneel et al. (2011) at the same university as used for this article, it was shown that most of the time students use computers and the Internet for relaxation. If this is the case, it is understandable that students will not invest too much time in acquiring knowledge about computers. If there is a maintenance problem, help can be sought from a friend who is more familiar with computers and the Internet. This might result in students who are more interested in attaining a certain level of achievement being less interested in learning more about solving minor computer problems that can easily be solved by a colleague or friend.

Most of the variables in Model 2 that are good predictors for the study efficiency of students have already been detected in Model 1. We list them here in descending order of predictive power: GPA in secondary school $(b=0.30)$; hours weekly spent on maths in secondary school $(b=0.24)$; ambivalent feelings about the choice of study $(b=-0.14)$; having studied classical languages in secondary school $(b=0.11)$; reading $(b=-0.08)$; intrinsic motivation $(b=0.06)$; and having a mother who graduated in higher education. In addition to Model 1, having a father with a higher 
education diploma and having some knowledge about the maintenance of a computer also improves prediction. Having a father with a higher education diploma $(b=0.06)$ or having little competence to maintain a computer $(b=-0.11)$ predicts a higher study efficiency. For an explanation of this relationship we refer to our above-mentioned hypothesis. No noticeable impact on study efficiency results from the gender of the student, the financial comfort of the parents, the scholarship of the student, the study path of the student, engagement in social activities, social contact skills, or basic ICT skills.

Prediction of the GPA for the first year at university can rely on the same variables as in Model 1, except that they are also supported by the knowledge students have of basic ICT skills ( $b=$ $0.06)$ and maintenance skills $(b=-0.12)$. The last two variables show higher values for GPA at the end of the first year at university when their score is low. For a hypothetical explanation for this odd relationship we refer to the comment given above in relation to the same phenomenon regarding the persistence of study choice. Other negative predictors are ambivalent feelings about the choice of study $(b=-0.13)$ and reading $(b=-0.06)$. Positive predictors are the GPA in the last year of secondary school $(b=0.36)$, weekly hours spent on the study of maths in secondary school $(b=0.25)$, study of classical languages in secondary school $(b=0.012)$, intrinsic motivation for study $(b=0.08)$, and higher education of father $(b=0.07)$ or mother $(b=0.05)$.

Just like for model 1, we also have applied model 2 on the subsample of humanities and social science students and the subsample of (biomedical) sciences. The statements made for model 1 can be made for model 2, but without the exceptions mentioned above. Nevertheless, an important difference between humanities and (biomedical) science students has been observed. ICT skills as measured in this research do not significantly contribute to predicting educational attainment of (biomedical) science students. This does not mean that ICT skills have no importance for these students. On the contrary, these students need these ICT skills and they also score significantly higher for basic ICT skills (score 3.7 out of 5) and maintenance skills (score $=4.04$ out of 5) than humanities and social science students (resp. score 3.3 and 3.88). On the other hand, for humanities and social science students, the negative predictive power of the maintenance skills for persistence of study choice $(b=-0.11 ; p=0.02)$, for study efficiency $(b=-0.14 ; p=0.0007)$, and for GPA $(b=-0.14 ; p=0.0004)$ is higher than in the analysis of the global sample. The same negative predictive power of the mastering of basic ICT skills for the GPA is found ( $b=-0.07 ; p$ $=0.05$ ). These data show that the knowledge of ICT skills as measured in this project can predict some indicators of education attainment of freshmen in humanities and social sciences, but not in (biomedical) sciences.

For exploratory purposes, we also tested models including interaction terms with gender and domain of study. Because very few of the interaction terms achieved statistical significance, these are not further discussed here.

\section{Discussion}

Starting from the observation that students these days can hardly survive at university if they do not attain a certain level of ICT competences, we hypothesized that ICT competences can contribute to the educational attainment of students at university. To check this hypothesis, a sample of freshmen at a large university was used. In the first step, an examination was made of how the traditional variables used in the academic pathways model could predict actual educational attainment, and, in the personal knowledge management model, ICT competences were added to the first model in order to examine whether this could improve the former predictions. We can conclude that some ICT competences, namely maintenance skills, are a help in better predicting educational attainment. However, the original hypothesis that students with a better command of maintenance skills also obtained higher educational attainment was not supported. Contrary to this finding, Tien and Fu (2008) concluded that the software knowledge of students was a good 
positive predictor for achievement. One of the reasons of this discrepancy may be found in the difference between the indicators for measuring ICT knowledge used in both researches. A replication with both instruments could confirm or refute one of the former statements.

Although it can hardly be denied that mastering the basic ICT skills that were investigated in this research are essential for the achievement of students, PKM theory shows that personal knowledge management transcends the possession of basic ICT skills. Faced with Web 2.0 techniques students can probably more easily take advantage of mastering the Web 2.0 tools without having to be well trained users of basic ICT skills. As Cigognini, Pettenati, and Edirisingha (2011) contend, personal knowledge management includes also the use of Web 2.0 tools (e.g., tagging, blogging, podcasting, social networking) in order to create, organize, or share knowledge. Different levels of mastering these 2.0 tools might show a better understanding of the achievement of students who live in a Web 2.0 world, as enhanced user interfaces are making it less necessary to master all basic ICT skills in order to be able to use the Web 2.0 tools.

We also want to stress that we expect that the original hypothesis may make sense if it is applied to a population other than 18 to 19 year-old university students. Indeed, in the last decade all kind of applications of ICT have become widespread throughout our society. The young generation has lived in a situation where the use of ICT was evident (see the section "ICT skills and access to computers and the Internet"). Most of them are "digital natives" and have had to learn some necessary techniques in order to work with ICT. This is not the case for the older generations. Therefore we think that it makes sense to check our original hypothesis over a wider population than university students.

In our explanatory model, the GPA in secondary school, the number of weekly hours spent on the study of mathematics, and whether the student studied classical languages are very important as explanatory variables. Although these are important factors it would make sense to study more indicators. St. John and Musoba (2011), for instance, use different categories of GPA, class rank, study of science, history, English, literature, and other foreign languages in secondary school. Adding in these factors could improve our explanatory model.

Two variables are used to provide an indication of the economic background of the student's family, namely, the judgement of the student about the financial comfort of the parents and the eligibility of the student for a scholarship. Both variables tell us something about the economic position of the family, but this is not as specific as using income categories (St. John \& Musoba, 2011). Nevertheless, we should not forget that information about income is not always reliable.

The variables of reading and engagement did not produce the expected results. Reading books can undeniably be connected with having cultural capital that normally supports increased educational attainment. Engagement with social contacts can also be seen as a basis for social capital, because it might form the foundations for social contacts that legitimize the position of a person in society and consequently his or her social capital (Bourdieu, 1986). Contrary to our expectations, engagement had no effect on educational attainment in this research and reading had a negative impact. This makes it clear that reading books and visiting a library are not sufficient specifications for assessing the influence of libraries and books on educational attainment. We assume that reading non-fiction and visiting scientific libraries would have produced a different result (see also Tien \& Fu, 2008). The rough indication of participation in cultural organizations, sport, or other types of organizations does not prove that these contacts enhance the cultural capital of the freshmen and consequently their educational attainment. We hypothesize that social contacts in study groups or the like could have a greater influence, because these types of groups will contribute to social capital that is useful for educational attainment.

In the section on the "Theoretical background" it was argued that technology-enhanced classrooms, CAI, e-learning, and the like may have a discernable influence on educational attainment 
(Carle et al., 2009; Pedro, 2005; Qayumi et al., 2004; Vernadakis et al., 2011), but it has also been demonstrated that the influence is not always positive (Hunley et al., 2005; Şendag \& Odabaşi, 2009; Svirko \& Mellanby, 2008). In this research we did not investigate CAI or e-learning. Our focus was on the self-perceived knowledge of the basic ICT competences that are required to work with CAI or e-learning. One of the factors we examined (social contact skills) was so widespread among the freshmen that it could not differentiate between the students. The two other ICT competence categories produced a negative relationship with educational attainment. This is most probably a consequence of the special position in our society of freshmen at university. Therefore it is meaningful to hypothesize that these variables could be linked to educational attainment for a population spread over all age categories.

Educational attainment has been measured using three indicators: persistence of study choice, study efficiency, and GPA at the end of the first academic year at university. Although we found an effect of the "classic" explanatory variables for educational attainment, we did not find any additional effect for most ICT skills. There could be a larger effect if we did not limit our research to the study results for only the first year. Possibly ICT is more necessary in later years, e.g., for more specialized courses. In other words, a global overview of educational attainment cannot be observed at the end of the first year at university. In this regard, it would be interesting to repeat this research at the end of basic university training and in more types of universities (see St. John \& Musoba, 2011), or even better, many years after finishing initial university training in order to see which students received a $\mathrm{PhD}$ and/or attended adult education.

These observations lead us to plead for further research concerning all facets of the personal and organizational knowledge management model among a wider population than freshmen in order to get a better picture of the meaning of ICT skills and Web 2.0 tools for educational attainment. Research paying attention at the limitations of this research will probably shed more light on the functioning of ICT skills and Web 2.0 tools for education attainment in our society.

Although these critical reflections on the weak and negative impact of the command of some ICT skills can reduce the belief in the positive meaning of these skills, they should not be forgotten in the training of students. Students cannot survive in the current educational system without a satisfactory level of command of ICT skills. This is necessary for attaining an acceptable level of educational achievement. But a command of basic ICT skills will not be sufficient. Indeed, our society needs not only personal knowledge management but also organizational knowledge management (Truch, 2001). In practice, universities should thoroughly reflect about how they can manage personal and organizational knowledge.

\section{Conclusion}

Two models were developed to explain the educational attainment of freshmen at university: one relies on the traditional variables used in this field of research and the second is composed of the traditional variables together with variables referring to the level of ICT competences of the students. In universities these days it is hard for a student to survive if they have no knowledge of some ICT skills, and, taking into account the current demands of universities on students, it was hypothesized that Model 2 would offer a better explanation than Model 1 (without ICT competences taken into account). Table 3 shows that the adj. $\mathrm{R}^{2}$ for the three forms of educational attainment in Model 1 and Model 2 differ slightly. It is also shown that both models demonstrate a better explanation for the GPA at the end of the first academic year (adj. $\mathrm{R}^{2}$ is resp. 0.34 and 0.36 ) than for study efficiency (adj. $\mathrm{R}^{2}$ is resp. 0.27 and 0.28 ) or for persistence of study choice (adj. $\mathrm{R}^{2}$ is resp. 0.12 and 0.13 ).

Contrary to our expectations, ICT social contact skills and basic ICT skills do not deliver a better prediction of educational attainment, whereas maintenance skills do. But also contrary to our ex- 
pectations, these skills predict a lower attainment $(b=-0.09,-0.11$ or -0.12 in Table 3$)$ when students score high for this variable. The reason for this may be found in the supporting function of computers and the Internet for study, and their greater importance for the relaxation of students. Study at university is more focused on the content of a discipline, and computers and the Internet are only devices that may make work easier. Of course, this is different for students for whom ICT is the subject for study.

Four predictors are very powerful for the explanation of educational attainment: the GPA in secondary school of the student, weekly hours spent on the study of maths in secondary school, study of classical languages in secondary school (see also St. John \& Musoba, 2011, p. 162), and ambivalent feelings about the chosen study (see also Van Bragt et al., 2011). The higher the scores of freshmen for GPA, maths, and classical languages in secondary school, the more persistent they are in study choice, and the higher the study efficiency and the GPA at the end of the first year at university. The best predictor is the GPA for the last year of secondary school, followed in importance by maths courses and classical languages in secondary school. The same hierarchy can be found for the explanation of the study efficiency and the GPA of humanities and social science students as well as biomedical and science students. Ambivalent feelings about study choice predict lower values for the three indicators of educational attainment.

The education level of the mother is also a good predictor for educational attainment, although weaker than the former predictors. If their mother attended higher education, students will score higher for persistence (only in Model 1), study efficiency and GPA at the end of the first year. Is this a consequence of the traditional educative role of the mother? Before we can accept this as evidence, more observation should be carried out into the educational role of mothers. If their father attended higher education, students score only higher for the GPA (in both models) and study efficiency in Model 2 (see also St. John \& Musabo, 2011, p. 162; Scherger \& Savage, 2010). In Taiwan, Tien and Fu (2008) did not find a confirmation of our observation. The education of the father or the mother could not predict anything with regard to the academic performance of students.

The intrinsic motivation for study is also a good predictor in both models for study efficiency and the GPA at the end of the first year (see also Ou, 2005). However, it does not explain why students leave their original study path or the university.

Contrary to what was expected, a high score for reading books and visiting libraries predicts a lower study efficiency and a lower GPA at the end of the first year (see also Ou, 2005). Educational attainment in the first year at university does not depend on reading any type of books, but it is most probably the result of more academic reading (Tien $\& \mathrm{Fu}, 2008$ ).

In comparison with other students, those studying humanities and social sciences are more persistent in following their first chosen study (in both models) and in Model 1 they also score higher for study efficiency (see also St. John \& Musabo, 2011, p. 162). It should be stressed that this does not mean that humanities and social sciences students are better than other students, because the indicator provides no information regarding the level of difficulty of the examinations.

It is interesting that gender, financial comfort of the parents, receiving a grant, and engagement in social contacts do not create a significant differentiation between freshmen concerning their educational attainment. This finding is not always supported by other researchers. For example, St. John and Musabo (2011) see that the within-year persistence is stronger among men than women (see also Scherger \& Savage, 2010), higher among students of families with a high income than among students of families with a low income, and higher among students who receive loans and/or grants. This is not confirmed in our research. 


\section{References}

Alavi, M., \& Leidner, D. E. (2001). Review: Knowledge management and knowledge management systems: Conceptual foundations and research issues. MIS Quarterly, 25(1), 107-136.

Bell, P. D. (2007). Predictors of college student achievement in undergraduate asynchronous web-based courses. Education, 127(4), 523-533.

Blau, P. M., \& Duncan, O. D. (1967). The American occupational structure. New York, London, Sydney: John Wiley \& Sons.

Bourdieu, P. (1986). The forms of capital. In J. G. Richardson (Ed.), Handbook of theory and research for the sociology of education (pp. 241-258). New York, Westport, London: Greenwood Press.

Bruneel, S., De Wit, K., Verhoeven, J. C., \& Elen, J. (2011). Help, my teacher is online! Educational use and privacy issues on Facebook. Manuscript submitted for publication.

Carle, A. C., Jaffee, D., \& Miller, D. (2009). Engaging college science students and changing academic achievement with technology: A quasi-experimental preliminary investigation. Computers \& Education, 52(2), 376-380.

Cigognini, M. E., Pettenati, M. C., \& Edirisingha, P. (2011). Personal knowledge management skills in Web 2.0-based learning. In M. J. W. Lee \& C. McLoughlin (Eds.), Web 2.0-based e-learning: Applying social informatics for tertiary teaching (pp. 109-127). Hershey, New York: Information Science Reference.

De Wit, K., Heerwegh, D., \& Verhoeven, J. C. (in press). Changes in the basic ICT skills of freshmen between 2005 and 2009: Who's catching up and who's still behind? Education and Information Technologies. Published online as doi: 10.1007/s10639-011-9154-z

Edwards, J. S., Ababneh, B., Hall, M., \& Shaw, D. (2009). Knowledge management: A review of the field and of OR's contribution. Journal of the Operational Research Society, 60,114-125. doi:10.1057/jors.2008.168

George, D., Dixon, S., Stansal, E., Gelb, S. L., \& Pheri, T. (2008). Time diary and questionnaire assessment of factors associated with academic and personal success among university undergraduates. Journal of American College Health, 56(6), 706-715.

Hargittai, E. (2010). Digital na(t)ives? Variation in Internet skills and uses among members of the "Net Generation'”. Sociological Inquiry, 80(1), 29-113.

Hunley, S. A., Evans, J. H., Delgado-Hachey, M., Krise, J., Rich, T., \& Schell, C. (2005). Adolescent computer use and academic achievement. Adolescence, 40(158), 307-318.

Lee, A. C. K. (2003). Undergraduate students' gender differences in IT skills and attitudes. Journal of Computer Assisted Learning, 19(4), 488-500.

Lleras, C. (2008). Do skills and behaviors in high school matter? The contribution of noncognitive factors in explaining differences in educational attainment and earnings. Social Science Research, 37(3), 888902.

Lytras, M. D., \& Pouloudi, A. (2006).Towards the development of a novel taxonomy of knowledge management systems from a learning perspective: An integrated approach to learning and knowledge infrastructures. Journal of Knowledge Management, 10(6), 64-80. doi: 10.1108/13673270610709224

Nelson Laird, T. F., \& Kuh, G. D. (2005). Student experiences with information technology and their relationship to other aspects of student engagement. Research in Higher Education, 46(2), 211-233.

Ou, S. (2005). Pathways of long-term effects of an early intervention program on educational attainment: Findings from the Chicago longitudinal study. Journal of Applied Development Psychology, 26(5), 578-611. 
Palaigeorgiou, G. E., Siozos, P. D., Konstantakis, N. I., \& Tsoukalas, I.A. (2005). A computer attitude scale for computer science freshmen and its educational implications. Journal of Computer Assisted Learning, 21(5), 330-342.

Pedro, F. (2005). Comparing traditional and ICT-enriched university teaching methods: Evidence from two empirical studies. Higher Education in Europe, 30(3-4), 399-411.

Pillay, H., Irving, K., \& Tones, M. (2007). Validation of the diagnostic tool for assessing tertiary students' readiness for online learning. Higher Education Research \& Development, 26(2), 217-234.

Punie, Y., \& Ala-Mutka, K. (2007). Future learning spaces: New ways of learning and new digital skills to learn. Digital Kompetanse. Nordic Journal of Digital Literacy, 2(4), 210-225.

Qayumi, A. K., Kurihara, Y., Imai, M., Pachev, G., Seo, H., Hoshino, Y., ... Kariya, Y. (2004). Comparison of computer-assisted instruction (CAI) versus traditional textbook methods for training in abdominal examination (Japanese experience). Medical Education, 38(10), 1080-1088.

Robbins, S. B., Lauver, K., Le, H., Davis, D., Langley, R., \& Carlstrom, A. (2004). Do psychological and study skill factors predict college outcomes? A meta-analysis. Psychological Bulletin, 130(2), 261-288.

Robertson, D. L., \& Reynolds, A. J. (2010). Family profiles and educational attainment. Children and Youth Services Review, 32(8), 1077-1085.

Scherger, S., \& Savage, M. (2010). Cultural transmission, educational attainment and social mobility. The Sociological Review, 58(3), 406-428.

Schmitt, J., \& Wadsworth, J. (2006). Is there an impact of household computer ownership on children's educational attainment in Britain? Economics of Education Review, 25(6), 659-673.

Schwartz, S. (2006). A context model for personal knowledge management applications. In T. H. RothBerghofer, S. Schulz, \& D. B. Leake (Eds.), Modeling and Retrieval of Context. Lecture notes in computer science, Volume 3946 (pp. 18-33). Berlin, Heidelberg: Springer Verlag. doi: $10.1007 / 11740674$

Şendag, S., \& Odabaşi, H. F. (2009). Effects of an online problem based learning course on content knowledge acquisition and critical thinking skills. Computers \& Education, 53(1), 132-141.

Sewell, W. H., Haller, A. O., \& Portes, A. (1969). The educational and early occupational attainment process. American Sociological Review, 34(1), 82-92.

St. John, E. P., \& Musoba, G. D. (2011). Pathways to academic success in higher education. Expanding opportunity for underrepresented students. New York and London: Routledge, Taylor \& Francis Group.

Svirko, E., \& Mellanby, J. (2008). Attitudes to e-learning, learning style and achievement in learning neuroanatomy by medical students. Medical Teacher, 30, e219-e227.

Tien, F. F., \& Fu, T. (2008). The correlates of the digital divide and their impact on college student learning. Computers \& Education, 50(1), 421-436.

Truch, E. (2001). Managing personal knowledge: The key to tomorrow's employability. Journal of Change Management, 2(2), 102-105.

Van Braak, J. P. (2004). Domains and determinants of university students self-perceived computer competence. Computers \& Education, 43(3). 299-312.

Van Bragt, C. A. C., Bakx, A. W. E. E., Bergen, T. C. M., \& Croon, M. A. (2011). Looking for students' personal characteristics predicting study outcome. Higher Education, 61, 59-75.

Van Steenkiste, M., Sierens, E., Soenens, B., Luyckx, K., \& Lens, W. (2009). Motivational profiles from a self-determination perspective: The quality of motivation matters. Journal of Educational Psychology, 101(3), 671-688. 
Vandenberg, R. J., \& Lance, C. E. (2000). A review and synthesis of the measurement invariance literature: Suggestions, practices, and recommendations for organizational research. Organizational Research Methods, 3(4), 4-70.

Verhoeven, J. C., Heerwegh, D., \& De Wit, K. (2010). Information and communication technologies in the life of university freshmen: An analysis of change. Computers \& Education, 55(1), 53-66.

Vermunt, J. (1994). Scoring key for the inventory of learning styles (ILS) in higher education. Tilburg: Tilburg University

Vernadakis, N., Antoniou, P., Giannousi, M., Zetou, E., \& Kioumourtzoglou, E. (2011). Comparing hybrid learning with traditional approaches on learning the Microsoft Office Power Point 2003 program in tertiary education. Computers \& Education, 56(1), 188-199.

Völkel, M., \& Haller, H. (2009). Conceptual data structures for personal knowledge management. Online Information Review, 33(2), 298-315. doi: 10.1108/14684520910951221

Wurst, C., Smarkola, C., \& Gaffney, M. A. (2008). Ubiquitous laptop usage in higher education: Effects on student achievement, student satisfaction, and constructivist measures in honors and traditional classrooms. Computers \& Education, 51(4), 1766-1783.

\section{Biographies}

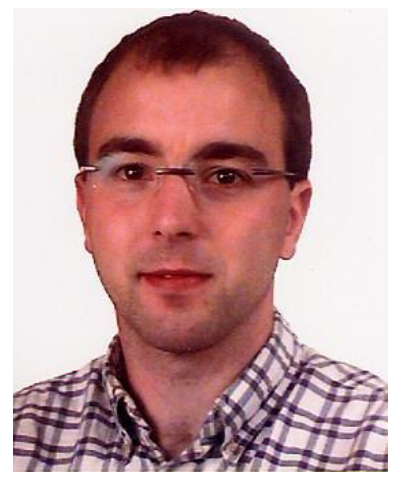

Kurt De Wit, Ph.D. in Sociology (K.U.Leuven), currently is a senior policy advisor at the Office for Educational Policy of the university of Leuven (K.U.Leuven) in Belgium. He monitors national and European higher education policy and carries out institutional research on students and education. He serves on the Executive Council of the Flemish Sociological Association and is editor-in-chief of its peer-reviewed journal (Tijdschrift voor Sociologie). His current research interests include education innovation policy in higher education, the roles of ICT for university students, international rankings of higher education institutions, governance and funding of higher education, and the development of the network society and its consequences for higher education.

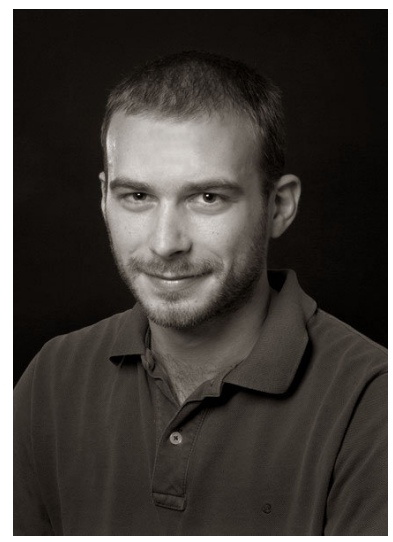

Dirk Heerwegh is a senior consultant specialized in data management and biostatistics at Business \& Decision Life Sciences (Belgium). In 2005, he has obtained his Ph.D. in the field of social survey methods at the University of Leuven (Belgium). His academic publications are in the fields of survey methodology, attitudes towards Europe, and the use of ICT. He has taught courses on data management, survey research methods, and statistics. 


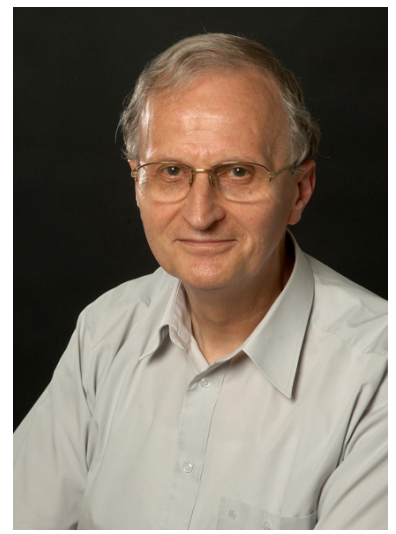

Jef C. Verhoeven is emeritus professor of sociology at the University of Leuven (Belgium). His recent research is focused on higher education and the use of ICT. He taught at several foreign universities (see https://perswww.kuleuven.be/ u0003309/School/EducationAndTheory indexhoogGuestE css.html). He published in the fields of theoretical sociology and sociology of education including many books, and articles in, among others, the European Journal of Education, Journal of Education Policy, Educational Management, Administration \& Leadership, Higher Education Policy, Teacher Development, Research on Language and Social Interaction, Studies in Higher Education, Education Policy Analysis Archives, Tsinghua Journal of Education, Teachers and Teaching - Theory and Practice, Journal of Shandong University (Philosophy and Social Sciences), Assessment in Education: Principles, Policy \& Practice, Computers \& Education - An International Journal, Education and Information Technologies, Frontiers of Education in China 